\title{
PENERAPAN MODEL PEMBELAJARAN KOOPERATIF TIPE TEAM ASSISTED INDIVIDUALIZATION (TAI) UNTUK MENINGKATKAN HASIL BELAJAR SISWA PADA BIDANG STUDI EKONOMI SMA NEGERI 1 PERCUT SEI TUAN
}

\author{
Tiamsa Napitupulu \\ Guru Mata Pelajaran Ekonomi SMA Negeri 1 Percut Sei Tuan \\ e-mail : rajo_hasim@yahoo.com
}

\begin{abstract}
Abstrak
Pembelajaran Ekonomi di SMA Negeri 1 Percut Sei Tuan belum memberikan ketuntasan belajar klasikal sehingga perlu diupayakan pembelajaran yang berorientasi pada aktivitas siswa. Penelitian tindakan kelas ini akan ditempuh dalam dua siklus. Penelitian dikenakan pada siswa kelas XII IPS-3 SMA Negeri Percut Sei Tuan dengan jumlah 33 siswa. Dari hasil penelitian disimpulkan bahwa: 1) Formatif I menunjukkan rata-rata 57,1 dengan ketuntasan klasikal 45\% dan Formatif II menunjukkan rata-rata 82,4 dengan ketuntasan secara klasikal $88 \%$ atau mencapai ketuntasan secara kalsikal dengan peningkatan ketuntasan klasikal 35\%;2) data aktivitas siswa rata-rata menurut pengamatan pengamat pada Siklus I antara lain menulis/membaca (38\%), mengerjakan LKS (29\%), bertanya sesama teman (8\%), bertanya kepada guru (17\%), dan yang tidak relevan dengan KBM (7\%), sedangkan data aktivitas siswa rata-rata pada Siklus II antara lain membaca (33\%), mengerjakan LKS (38\%), bertanya sesama teman (20\%), bertanya kepada guru (7\%), dan yang tidak relevan dengan KBM (3\%).
\end{abstract}

Kata Kunci : Model Pembelajaran, Kooperatif , Hasil Belajar Siswa

\section{PENDAHULUAN}

Pembelajaran adalah proses pengelolaan lingkungan seseorang yang dengan sengaja dilakukan sehingga memungkinkan dia belajar melakukan atau mempertunjukkan tingkah laku tertentu. Sedangkan belajar adalah suatu proses yang menyebabkan perubahan tingkah laku yang bukan disebabkan oleh proses pertumbuhan yang bersifat fisik, tetapi perubahan dalam kebiasaan, kecakapan, bertambah, berkembang daya pikir, sikap dan lain-lain. (Soetomo, 1993: 120). Tugas guru yang utama adalah mengajar, yaitu menyampaikan atau mentransfer ilmu kepada anak didiknya. Oleh karena itu seorang dituntut untuk menguasai materi sesuai dengan bidangnya. Motivasi belajar tidak akan terbangun apabila siswa masih merasa kesulitan dalam menerima pelajaran. Bidang studi ekonomi dianggap sebagai pelajaran yang membosankan, sehingga jangan disalahkan apabila disetiap jam pelajaran ekonomi siswa cenderung merasa enggan dan malas. Untuk mengantisipasi hal tersebut perlu ada solusi dalam penyampaian mata pelajaran ekonomi dengan 
menggunakan berbagai cara yang menarik yang ada kaitannya dengan kehidupan sehari-hari. Pengalaman peneliti/guru selama mengajar di SMAN 1 Percut Sei Tuan, pelajaran ekonomi sering diinterpretasikan dengan aktivitas utama yang dilakukan guru, yaitu guru mengenalkan materi, mungkin mengajukan satu atau dua pertanyaan, dan meminta siswa yang pasif untuk aktif dengan memulai melengkapi latihan dari buku teks, pelajaran diakhiri dengan pengorganisasian yang baik dan pembelajaran selanjutnya dilakukan dengan sekenario yang serupa, berulang-ulang selain tidak mengembangkan kemampuan berpikir siswa pembelajaran berlangsung dengan suasana kejenuhan dan menurunkan minat belajar siswa. Melihat kondisi di atas perlu adanya perubahan strategi belajar mengajar di sekolah agar aktivitas dan hasil belajar siswa akan lebih baik.

Sebagian dari permasalahan

yang dihadapi yaitu berkenaan dengan rendahnya kemampuan guru dalam mengelola proses pembelajaran yang efektif. Pembelajaran semacam itu bukan saja membuat bosan para siswanya, namun juga membuat pemikiran mereka kurang berkembang, siswa kurang dilatih untuk peka terhadap permasalahan di sekitar dan belajar bagaimana memecahkan masalah menurut kemampuannya. Oleh sebab itu, perlu diadakan perubahan model pembelajaran seperti model pembelajaran kooperatif tipe TAI (Team Accelerated Instruction). Pembelajaran kooperatif tipe TAI (Team Accelerated Instruction) ini mengkombinasikan keunggulan pembelajaran kooperatif dan pembelajaran individual. Tipe ini dirancang untuk mengatasi kesulitan belajar siswa secara individual. Oleh karena itu, kegiatan pembelajarannya lebih banyak digunakan untuk pemecahan masalah, ciri khas pada tipe TAI ini adalah setiap siswa secara individual belajar materi pembelajaran yang sudah dipersiapkan oleh guru. Hasil belajar individual dibawa ke kelompokkelompok untuk didiskusikan dan saling dibahas oleh anggota kelompok, dan semua anggota kelompok bertanggung jawab atas keseluruhan jawaban sebagai tanggung jawab bersama.

Model pembelajaran TAI (Team Accelerated Instruction) termasuk dalam pembelajaran kooperatif. Dalam model pembelajaran TAI, siswa ditempatkan dalam kelompokkelompok kecil yang heterogen untuk menyelesaikan tugas kelompok yang sudah disiapkan oleh guru, selanjutnya diikuti dengan pemberian bantuan secara individu bagi siswa yang memerlukannya. Keheterogenan kelompok mencakup jenis kelamin, ras, agama (kalau mungkin), tingkat kemampuan (tinggi, sedang, rendah), dan sebagainya

Membuat model ini dengan beberapa alasan. Pertama, model ini 
mengkombinasikan keunggulan kooperatif dan program pengajaran individual. Kedua, model ini memberikan tekanan pada efek sosial dari belajar kooperatif. Ketiga, TAI disusun untuk memecahkan masalah dalam program pengajaran, misalnya dalam hal kesulitan belajar siswa secara individual.

Berdasarkan latar belakang di atas, maka dapat dirumuskan suatu masalah sebagai berikut; 1) Bagaimana hasil belajar siswa setelah menerapkan Model Pembelajaran Kooperatif Type Assisted Individualization pada mata pelajaran ekonomi di kelas XII IPS-3 SMAN 1 Percut Sei Tuan Tahun Pembelajaran 2014/2015?; 2) Bagaimana aktivitas belajar siswa setelah menerapkan Model Pembelajaran Kooperatif Type Assisted Individualization pada mata pelajaran ekonomi di kelas XII IPS-3 SMAN 1 Percut Sei Tuan Tahun Pembelajaran 2014/2015?.

Sesuai dengan permasalahan di atas, penelitian ini bertujuan untuk; 1) Untuk mengetahui hasil belajar siswa setelah menerapkan Model Pembelajaran Kooperatif Type Assisted Individualization pada mata pelajaran pelajaran ekonomi di kelas XII IPS-3 SMAN 1 Percut Sei Tuan Tahun Pembelajaran 2014/2015; 2). Untuk mengetahui aktivitas belajar siswa setelah menerapkan Model Pembelajaran Kooperatif Type Assisted Individualization pada mata pelajaran pelajaran ekonomi di kelas
XII IPS-3 SMAN 1 Percut Sei Tuan

Tahun Pembelajaran 2014/2015.

Model pembelajaran TAI (Team Assisted Individualization) termasuk dalam pembelajaran kooperatif. Menurut (Slavin, 2006: 19) "Dalam model pembelajaran TAI siswa ditempatkan dalam kelompok-kelompok kecil (4 sampai 5 siswa) yang heterogen untuk menyelesaikan tugas kelompok yang sudah disiapkan oleh guru, selanjutnya diikuti dengan pemberian bantuan secara individu bagi siswa yang memerlukannya" Keheterogenan kelompok mencakup jenis kelamin, ras, agama (kalau mungkin), tingkat kemampuan (tinggi, sedang, rendah), dan sebagainya. membuat model ini dengan beberapa alasan. Pertama, model ini mengkombinasikan keunggulan kooperatif dan program pengajaran individual. Kedua, model ini memberikan tekanan pada efek sosial dari belajar kooperatif. Ketiga, TAI disusun untuk memecahkan masalah dalam program pengajaran, misalnya dalam hal kesulitan belajar siswa secara individual.

Menurut (Suyitno 2004: 8) "Model pembelajaran tipe TAI ini memiliki 8 komponen, kedelapan komponen tersebut adalah sebagai berikut:

a. Teams yaitu pembentukan kelompok heterogen yang terdiri dari 4 sampai 5 siswa

b. Placement Test yaitu pemberian pre-test kepada siswa atau melihat rata-rata nilai harian siswa agar guru 
mengetahui kelemahan siswa pada bidang tertentu

c. Student Creative yaitu melaksanakan tugas dalam suatu kelompok dengan menciptakan dimana keberhasilan individu ditentukan oleh keberhasilan kelompoknya

d. Team Study yaitu tahapan tindakan belajar yang harus dilaksanakan oleh kelompok dan guru memberikan bantuan secara individual kepada siswa yang membutuhkan

e. Team Score and Team Recognition yaitu pemberian score terhadap hasil kerja kelompok dan memberikan kriteria penghargaan terhadap kelompok yang berhasil secara cemerlang dan kelompok yang dipandang kurang berhasil dalam menyelesaikan tugas

f. Teaching Group yaitu pemberian materi secara singkat dari guru menjelang pemberian tugas kelompok

g. Fact test yaitu pelaksanaan tes-tes kecil berdasarkan fakta yang diperoleh siswa

h. Whole-Class Units yaitu pemberian materi oleh guru kembali diakhiri waktu pembelajaran dengan strategi pemecahan masalah.
Tahap-tahap dalam model pembelajaran TAI adalah sebagai berikut:

a. Guru menyiapkan materi bahan ajar yang akan diselesaikan oleh kelompok siswa

b. Guru memberikan pre-test kepada siswa atau melihat rata-rata nilai harian siswa agar guru mengetahui kelemahan siswa pada bidang tertentu. (Mengadopsi komponen Placement Test)

c. Guru memberikan materi secara singkat. (Mengadopsi komponen Teaching Group)

d. Guru membentuk kelompok kecil yang heterogen tetapi harmonis berdasarkan nilai ulangan harian siswa, setiap kelompok 4-5 siswa. (Mengadopsi komponen Teams)

e. Setiap kelompok mengerjakan tugas dari guru berupa LKS yang telah dirancang sendiri sebelumnya, dan guru memberikan bantuan secara individual bagi yang memerlukannya.

(Mengadopsi komponen Team Study)

f. Ketua kelompok melaporkan keberhasilan kelompoknya dengan mempresentasikan hasil kerjanya dan siap untuk diberi ulangan oleh guru. (Mengadopsi komponen Student Creative) 
g. Guru memberikan post-test untuk dikerjakan secara individu. (Mengadopsi komponen Fact Test)

h. Guru menetapkan kelompok terbaik sampai kelompok yang kurang berhasil (jika ada) berdasarkan hasil koreksi. (Mengadopsi komponen Team Score and Team Recognition). Guru memberikan tes formatif sesuai dengan kompetensi yang ditentukan.

\section{METODOLOGI PENELITIAN}

\section{Lokasi dan Waktu Penelitian}

Penelitian

dilaksanakan

dengan pengambilan data di SMA

Negeri 1 Percut sei Tuan Jln. Irian barat No. 37, Sampali dan pelaksanaannya pada bulan April sampai dengan Juli Tahun Pelajaran 2014/2015. Pengambilan data dilaksanakan dalam empat kali pertemuan yang dibagi dalam dua siklus.

\section{Subjek Penelitian}

Subjek yang digunakan dalam penelitian ini adalah seluruh siswa kelas XII IPS-3 SMA Negeri 1 Percut Sei Tuan Tahun Pelajaran 2014/2015, dengan jumlah siswa yang terikut dalam penelitian sebanyak 33 orang.

\section{Alat Pengumpul Data}

Alat pengumpul data dalam penelitian ini adalah; 1) tes hasil belajar; 2) lembar observasi aktivitas siswa.

\section{Jenis dan Desain Penelitian}

Penelitian ini berbentuk Penelitian Tindakan Kelas (PTK). PTK pertama kali diperkenalkanoleh psikologi sosial Amerika yang bernama Kurt Lewin pada tahun 1946 (Aqib, 2006 :13).

Penelitian tindakan kelas adalah penelitian yang dilakukan oleh guru di kelas atau disekolah dengan penekanan pada penyempurnaan atau peningkatan proses pembelajaran.Menurut Lewin dalam Aqib (2006 : 21) menyatakan bahwa dalam satu Siklus terdiri atas empat langkah, yaitu perencanaan (planning), tindakan (acting), observasi (observing) dan refleksi (reflecting).

\section{Teknik Analisis Data}

Metode Analisis Data pada penelitian ini digunakan metode deskriptif dengan membandingkan hasil belajar siswa sebelum tindakan dengan hasil belajar siswa setelah tindakan.

Langkah-langkah pengolahan data sebagai berikut:

a. Merekapitulasi nilai pretes sebelum tindakan dan nilai tes akhir Siklus I dan Siklus II.

b. Menghitung nilai rerata atau persentase hasil belajar siswa sebelum dilakukan tindakan dengan hasil belajar setelah dilakukan tindakan pada Siklus I dan Siklus II untuk mengetahui adanya peningkatan hasil belajar. 


\section{Kriteria Keberhasilan}

Sebagai tolak ukur keberhasilan penelitian tindakan kelas ini dapat dilihat hasil belajar yang dikonfirmasi dengan kriteria ketuntasan minimal (KKM) ekonomi untuk kelas XII IPS di SMA Negeri 1 Percut Sei Tuan sebesar 75, jika hasil belajar siswa mencapai KKM secara individual dan $\geq 85 \%$ jumlah siswa memperoleh nilai $\geq \mathrm{KKM}$ maka pembelajaran tuntas secara klasikal.

\section{HASIL PENELITIAN DAN PEMBAHASAN}

\section{Hasil Penelitian}

Berikut ini akan dijelaskan kondisi awal siswa kelas XII IPS-3 yang menyangkut hasil belajar siswa pada mata pelajaran ekonomi. Untuk mempertegas identifikasi tersebut dilakukan pretes terhadap kelas XII IPS-3. Dari tes awal diperoleh nilai terendah 0 dan tertinggi 40 . Dengan rata-rata 22,7 dan KKM 75 maka ketuntasan klasikal 0\% sehingga dapat disimpulkan bahwa kemampuan awal siswa dalam materi pembelajaran sangat rendah. Meski dapat dipahami karena siswa belum mempelajari materi tersebut di sekolah, namun juga menggambarkan bahwa kepedulian siswa untuk membaca materi baru di rumah masih rendah.

\section{Siklus I}

\section{Tahap Observasi}

Observasi menghasilkan data aktivitas belajar siswa yang belum begitu menunjukkan siswa aktif diskusi. Data hasil observasi aktivitas belajar siswa disajikan dalam Tabel .1.

Tabel .1. Skor Aktivitas Belajar Siswa Siklus I

\begin{tabular}{|c|l|c|c|}
\hline No & \multicolumn{1}{|c|}{ Aktivitas } & Skor & Proporsi \\
\hline 1 & Menulis,membaca & 16.5 & $33 \%$ \\
\hline 2 & $\begin{array}{l}\text { Mengerjakan } \\
\text { LKS }\end{array}$ & 18.75 & $38 \%$ \\
\hline 3 & $\begin{array}{l}\text { Bertanya pada } \\
\text { teman }\end{array}$ & 9.75 & $20 \%$ \\
\hline 4 & $\begin{array}{l}\text { Bertanya pada } \\
\text { guru }\end{array}$ & 3.5 & $7 \%$ \\
\hline 5 & $\begin{array}{l}\text { Yang tidak } \\
\text { relevan }\end{array}$ & 1.5 & $3 \%$ \\
\hline \multicolumn{2}{|l|}{ Jumlah } & 50 & $100 \%$ \\
\hline
\end{tabular}

Merujuk pada Tabel .1. aktivitas dominan yang dilakukan siswa adalah menulis dan membaca (38\%) kondisi ini belum sesuai dengan yang diharapkan karena seharusnya aktivitas diskusi lebih dominan ketimbang aktivitas individual tersebut, sementara aktivitasi mengerjakan LKS dalam posisi kedua (29\%), bertanya pada guru $(17 \%)$ atau siswa masih sangat bergantung pada guru. Dan aktivitas bertanya pada teman dan yang tidak relevan berturut-turut $8 \%$ dan $7 \%$.

Pada akhir proses belajar mengajar siswa diberi tes Formatif I dengan tujuan untuk mengetahui tingkat keberhasilan siswa dalam proses belajar mengajar yang telah dilakukan. Adapun data hasil formatif pada Siklus I ditunjukkan Tabel .2. 
Tabel .2. Distribusi Hasil Formatif 1

\begin{tabular}{|c|c|c|c|}
\hline Nilai & Frekunsi & Ketuntasan & Rata-rata \\
\hline 100 & 2 & $6 \%$ & \\
\cline { 1 - 3 } 80 & 13 & $39 \%$ & \multirow{2}{*}{57,1} \\
\hline 60 & 15 & - & \\
\hline 40 & 3 & - & \\
\cline { 1 - 3 } Jumlah & 33 & $45 \%$ & \\
\hline
\end{tabular}

Merujuk pada Tabel .2. tersebut, nilai terendah Formatif I adalah 40 dan tertinggi adalah 100 . Merujuk pada KKM sebesar 75 maka hanya 15 dari 33 orang siswa mendapat nilai ketuntasan atau ketuntasan klasikal tercapai sebesar $45 \%$. Nilai ini berada di bawah kriteria ketuntasan klasikal sebesar $85 \%$ sehingga dapat dikatakan KBM Siklus I gagal memberi ketuntasan belajar dalam kelas. Nilai rata-rata kelas adalah 57,1 masih di bawah KKM. Dengan demikian maka peneliti berusaha melakukan tindakan perbaikan dalam melaksanakan pembelajaran Siklus II yang dirasa perlu.

\section{Tahap Refleksi I}

Berdasarkan hasil observasi dan interpretasi tindakan pada Siklus I, peneliti melakukan analisis kelemahan dalam Siklus I ini adalah:

a. Beberapa siswa belum memahami peran dan tugasnya dalam bekerja kelompok karena belum terbiasa dengan model pembelajaran yang diterapkan. b. Interaksi antar siswa belum berjalan dengan baik karena siswa belum terbiasa untuk menyampaikan pendapatnya kepada sesama teman lainnya dalam menyelesaikan masalah.

c. Adanya siswa yang pasif dan menggantungkan permasalahan yang dihadapi kepada kelompoknya.

d. Dalam diskusi kelompok hanya didominasi oleh beberapa siswa yang lebih mampu/pandai

e. Pada saat penyajian hasil diskusi kelompok hanya beberapa kelompok saja yang menyajikan hasil diskusi kelompoknya karena waktu yang tidak memungkinkan.

f. Siswa belum aktif dalam diskusi sehingga guru tidak memiliki cukup waktu untuk melakukan pembimbingan secara merata.

\section{Siklus II}

\section{Tahap Observasi}

Observasi yang dilakukan dua guru sejawat menghasilkan data aktivitas belajar siswa Siklus II yang mengalami perbaikan dibandingkan Siklus sebelumnya. Data hasil observasi aktivitas belajar siswa disajikan dalam Tabel .3. 
Tabel .3. Skor Aktivitas Belajar

Siswa Siklus II

\begin{tabular}{|c|l|c|c|}
\hline No & \multicolumn{1}{|c|}{ Aktivitas } & Skor & Proporsi \\
\hline 1 & Menulis,membaca & 16.5 & $33 \%$ \\
\hline 2 & $\begin{array}{l}\text { Mengerjakan } \\
\text { LKS }\end{array}$ & 18.75 & $38 \%$ \\
\hline 3 & $\begin{array}{l}\text { Bertanya pada } \\
\text { teman }\end{array}$ & 9.75 & $20 \%$ \\
\hline 4 & $\begin{array}{l}\text { Bertanya pada } \\
\text { guru }\end{array}$ & 3.5 & $7 \%$ \\
\hline 5 & $\begin{array}{l}\text { Yang tidak } \\
\text { relevan }\end{array}$ & 1.5 & $3 \%$ \\
\hline \multicolumn{2}{|l|}{ Jumlah } & 50 & $100 \%$ \\
\hline
\end{tabular}

Merujuk pada Tabel .3. aktivitas dominan yang dilakukan siswa adalah mengerjakan LKS (38\%) kondisi ini telah sesuai dengan yang diharapkan karena seharusnya aktivitas kerja memang lebih dominan ketimbang aktivitas individual menulis dan membaca yang berada pada peringkat kedua (33\%), bertanya pada guru turun menjadi $7 \%$ atau siswa mulai mandiri. Hal ini diperkuat dengan aktivitas bertanya pada teman dan yang tidaka relevan berturut-turut $20 \%$ dan $3 \%$.

Pada akhir proses belajar mengajar Siklus II siswa diberi tes Formatif II dengan tujuan untuk mengetahui tingkat keberhasilan siswa dalam proses belajar mengajar yang telah dilakukan. Adapun data hasil formatif pada Siklus II ditunjukkan Tabel .4.
Tabel 4. Distribusi Hasil Formatif II

\begin{tabular}{|c|c|c|c|}
\hline Nilai & $\begin{array}{c}\text { Frekun } \\
\text { si }\end{array}$ & $\begin{array}{c}\text { Ketuntasa } \\
\text { n }\end{array}$ & $\begin{array}{r}\text { Rata } \\
\text {-rata }\end{array}$ \\
\hline 100 & 8 & $24 \%$ & \\
\hline 80 & 21 & $64 \%$ & \\
\cline { 1 - 3 } 60 & 4 & - & \multirow{2}{*}{82,4} \\
\cline { 1 - 3 } 40 & 0 & - & \\
\cline { 1 - 2 } $\begin{array}{c}\text { Jumla } \\
\text { h }\end{array}$ & 33 & $88 \%$ & \\
\hline
\end{tabular}

Merujuk pada Tabel 4. tersebut nilai terendah Formatif II adalah 40 dan tertinggi adalah 100 . Merujuk pada KKM sebesar 75 maka 29 dari 33 orang siswa mendapat nilai ketuntasan atau ketuntasan klasikal tercapai sebesar $88 \%$. Nilai ini berada di atas kriteria ketuntasan klasikal sebesar $85 \%$ sehingga dapat dikatakan KBM Siklus II berhasil memberi ketuntasan belajar dalam kelas. Nilai rata-rata kelas adalah 82,4 telah mencapai KKM. Dengan demikian maka penelitian telah berhasil memberi ketuntasan klasikal dalam dua siklus.

\section{Tahap Refleksi II}

Pada saat melakukan diskusi dilakukan penilaian aktivitas melalui lembar observasi aktivitas. Data peningkatan hasil belajar sejalan dengan aktivitas belajar siswa yang kecenderungannya membaik. Secara umum terjadi perubahan aktivitas belajar siswa dari Siklus I ke Siklus II. Merujuk pada Tabel 1. pada Siklus I terlihat dari aktivitas individual menulis dan membaca 
sebesar $38 \%$ dan aktivitas mengerjakan LKS hanya mencapai $29 \%$. Aktivitas bertanya pada teman sebesar 8\%. Aktivitas bertanya kepada guru $17 \%$ dan aktivitas yang tidak relevan dengan KBM sebesar $7 \%$.

Merujuk pada Gambar 4.1 perbandingan antara Siklus I dengan Siklus II dijabarkan, aktivitas menulis dan membaca turun dari $38 \%$ menjadi 33\%. Aktivitas mengerjakan LKS meningkat dari $29 \%$ menjadi $38 \%$ menunjukkan perbaikan yang terjadi dalam proses pembelajaran. Sementara aktivitas bertanya pada teman naik dari $8 \%$ menjadi $20 \%$ dan bertanya pada guru turun dari $17 \%$ menjadi $7 \%$. Aktivitas yang tidak relevan dengan KBM pada turun dari $7 \%$ menjadi $3 \%$.

Setelah berlangsungnya

Siklus II, peneliti melakukan tes akhir Siklus II yakni Formatif II dengan perolehan nilai rata-rata 82,4 dan ketuntasan klasikal 88\%. Dengan demikian hasil Formatif II menyatakan bahwa pembelajaran Siklus II telah berhasil meningkatkan hasil belajar siswa dan memberikan ketuntasan rata-rata hasil belajar serta mampu memberikan ketuntasan belajar secara klasikal.

\section{Pembahasan}

Penerapan model Teams Accelerated Instruction atau Teams Assisted Individualization (TAI) merupakan penelitian tindakan kelas yang bertujuan untuk meningkatkan hasil belajar ekonomi siswa.
Penelitian dilakukan dengan menerapkan dua siklus pembelajaran dengan metode yang sama pada tiap siklusnya, yaitu metode Teams Assisted Individualization (TAI). Berdasarkan tabel data yang disajikan pada Siklus I sampai Siklus II pada deskripsi hasil penelitian di atas diperoleh hasil belajar ekonomi siswa yang mengalami peningkatan terlihat dari Gambar 2.

Merujuk pada Gambar 2, nilai terendah untuk pretes adalah 0 dan tertinggi adalah 50 dengan $\mathrm{KKM}$ (kriteria ketuntasan minimum) sebesar 75 maka tidak seorang pun mendapat nilai diatas ketuntasan atau ketuntasan klasikal adalah 0\% dan nilai rata-rata kelas adalah 22,7. Dari data tersebut dapat disimpulkan bahwa siswa tidak mempersiapkan diri dengan belajar dirumah sebelum datang ke sekolah.

Dalam diskusi antara peneliti dengan pembimbing penelitian maka dirumuskan penggunaan model pembelajaran kooperatif tipe TAI beserta penyusunan perangkat dan instrument penelitian sebagai perencanaan Siklus I. Perencanaan selanjutnya untuk melaksanakan tindakan pada Siklus I diawali dengan membagi kelompokkelompok diskusi sesuai dengan metode pembelajaran kooperetif Tipe TAI (Team Assisted Individualization). Dari jumlah keseluruhan siswa dalam kelas XII IPS-3 yaitu 33 siswa akan dibagi menjadi 6 kelompok belajar dan masing-masing kelompok terdiri dari 5-6 siswa yang heterogen. 
Pembagian kelompok didasarkan pada nilai pretes sehingga pembentukan kelompok memenuhi kriteria heterogen dalam kemampuan awal. Pada tahap perencanaan peneliti mempersiapkan beberapa komponen terkait dengan materi yang akan disampaikan. Hal-hal yang direncanakan pada Siklus I antara lain:

a. Menyiapkan silabus berdasarkan kurikulum yang digunakan (lampiran).

b. Membuat

Rencana

Pelaksanaan pembelajaran (RPP) tentang materi yang akan diajarkan (lampiran).

c. Menyiapkan LKS.

d. Menyiapkan media yang akan digunakan dalam proses pembelajaran.

e. Menyusun dan menyiapkan angket dan lembar observasi untuk mengukur minat siswa dan aktivitas siswa terhadap pelajaran ekonomi (lampiran)

f. Membagi kisi-kisi tes hasil belajar siswa yang digunakan pada pretes menjadi dua bagian dengan indikator yang dipelajari pada Siklus I sebagai Formatif I dan indikator pada Siklus II sebagai Formatif II.

Siklus I dilaksanakan dalaam

dua kali pertemuan. Proses pembelajaran dilakukan sesuai RPP yang telah disusun untuk Siklus I. Pada pelaksanaan pembelajaran Siklus I ini guru sebagai peneliti dibantu guru sejawat yang bertindak sebagai observer yang membantu peneliti mengamati aktivitas belajar siswa.

Setelah berakhirnya pelaksanaan Siklus I diadakan tes hasil belajar kognitif yang selanjutnya disebut sebagai Formatif I. Merujuk pada Gambar 2 tersebut, nilai terendah Formatif I adalah 40 dan tertinggi adalah 100. Merujuk pada KKM sebesar 75 maka 15 dari 33 siswa mendapat nilai mencapai kriteria ketuntasan atau ketuntasan klasikal adalah sebesar $45 \%$. Nilai ini berada di bawah kriteria ketuntasan klasikal sebesar 85\% sehingga dapat dikatakan KBM Siklus I tidak berhasil memberi ketuntasan belajar dalam kelas. Nilai rata-rata kelas adalah 57,1 yang berarti di bawah KKM. Berdasarkan hasil belajar kognitif dan pengamatan Siklus I menunjukkan bahwa masih terdapat beberapa permasalahan/kekurangan dalam pelaksanaan tindakan yang perlu diperbaiki secara lanjut. Beberapa kelemahan pada Siklus I yang ditemukan yaitu:

a. Beberapa siswa belum memahami peran dan tugasnya dalam bekerja kelompok karena belum terbiasa dengan model pembelajaran yang diterapkan.

b. Interaksi antar siswa belum berjalan dengan baik karena siswa belum terbiasa untuk menyampaikan pendapatnya kepada sesama teman lainnya dalam menyelesaikan masalah. 
c. Adanya siswa yang pasif dan menggantungkan permasalahan yang dihadapi kepada kelompoknya.

d. Dalam diskusi kelompok hanya didominasi oleh beberapa siswa yang lebih mampu/pandai.

e. Pada saat penyajian hasil diskusi kelompok hanya beberapa kelompok saja yang menyajikan hasil diskusi kelompoknya karena waktu yang tidak memungkinkan.

f. Siswa belum aktif dalam diskusi sehingga guru tidak memiliki cukup waktu untuk melakukan pembimbingan secara merata.

Berdasarkan kekurangankekurangan yang ada pada Siklus I tersebut, maka diperlukan adanya perbaikan pada Siklus II. Perbaikan yang akan dilakukan didiskusikan peneliti bersama guru sejawat, pembimbing dan pendamping. Setelah dilakukan diskusi dihasilkan beberapa tindaka yang sebaiknya dilakukan. Adapun perbaikan pada Siklus II adalah:

a. Melakukan pembagian kerja dalam kelompok sehingga tiap anggota kelompok memiliki tugas dan tanggung jawab pribadi.

b. Untuk mengatasi efisiensi pembimbingan dan mengarahkan kerja kelompok serta menekan dominasi siswa tertentu maka siswa unggul dijadikan tutor dalam kelompok

dengan memberikan aturan-aturan tertentu.

c. Di akhir pembelajaran diberikan tugas individual berdasarkan hasil diskusi sehingga setiap siswa merasa berkepentingan memahami hasil diskusi kelompoknya.

Merujuk pada Gambar 4, nilai terendah Formatif II adalah 60 dan tertinggi adalah 100 dengan 29 dari 33 siswa mendapat nilai mencapai KKM atau ketuntasan klasikal adalah sebesar $88 \%$. Nilai ini telah berada di atas kriteria keberhasilan sehingga dapat dikatakan KBM Siklus II telah berhasil memberi ketuntasan belajar pada siswa dalam kelas. Nilai ratarata kelas adalah 82,4 telah memenuhi KKM.

Dengan demikian tindakan yang diberikan pada Siklus II telah berhasil memberikan perbaikan hasil belajar pada siswa. Hal ini dipengaruhi beberapa faktor diantaranya adalah sebagai berikut:

a. Siswa sudah mulai terbiasa dengan bekerja secara kelompok atau berdiskusi ditunjukkan oleh naiknya aktivitas mengerjakan LKS (38\%).

b. Keberanian siswa untuk berinteraksi berjalan dengan baik karena siswa sudah mulai terbiasa untuk bertanya dan menyampaikan pendapatnya kepada sesama teman lainya dalam menyelesaikan masalah ditunjukkan naiknya aktivitas interaksi antar siswa (20\%). 
c. Siswa mulai aktif dan tahu akan tugasnya sehingga tidak menggantungkan

permasalahan yang dihadapi kepada teman dalam kelompoknya ditunjukkan dengan menyusutnya aktivitas menulis dan membaca (33\%).

d. Karena siswa sudah aktif dalam diskusi kelompok maka guru dapat membimbing siswa pada saat diskusi secara merata sehingga diskusi dapat berjalan lebih efektif terlihat dari dokumentasi penelitian.

Pada Siklus II, pelaksanaan pembelajaran kooperatif tipe TAI, tindakan berupa menampilkan media chart dan pemberian penugasan yang memunculkan banyak aktivitas sudah efektif. Hal ini terlihat dari aktivitas siswa pada Siklus II yang lebih baik dari pada Siklus I, meski kenaikan aktivitas individual seperti menulis dan membaca terjadi pada Siklus II namun kondisi yang terjadi adalah seimbang antara aktivitas individu tersebut dengan aktivitas kelompok yang berarti pula bahwa siswa terlibat aktif dalam pembelajaran. Kesimpulan ini diperkuat dengan temuan bahwa aktivitas yang tidak relevan dengan KBM pada Siklus II menyusut mencapai $3 \%$.

Dengan demikian proses pembelajaran yang dilaksanakan guru pada Siklus II sudah memenuhi komponen-komponen dalam pembelajaran kooperatif tipe TAI. Menurut Suyitno (2004: 9) model pembelajaran kooperatif tipe TAI mempunyai 8 (delapan) komponen yaitu: placement test, teaching group, teams, student creative, team study, team score, recognition, whole class units.

Berdasarkan hasil observasi aktivitas diskusi kelompok dan hasil tes pada Siklus II dapat dievaluasi bahwa langkah-langkah yang telah diprogramkan dan dilaksanakan mampu mencapai tujuan yang diharapkan dalam penelitian. Dengan demikian pembelajaran kooperatif tipe TAI dapat memperbaiki aktivitas dan meningkatkan hasil belajar dan memberikan kompetensi pada siswa tanpa tambahan waktu. Dengan demikian berarti percepatan pencapaian kompetensi berhasil dilakukan dengan menerapkan model ini.

Selain itu pembelajaran kooperatif tipe TAI positif terhadap respon siswa dalam pembelajaran yang tampak dari kuisioner yang diberikan dimana siswa kelihatan lebih tertarik terhadap mata pelajaran dan keingintahuannya sedikit lebih tinggi yang mengindikasikan bahwa ketertarikan siswa terhadap pelajaran karena keingintahuannya. Sementara efek pembelajaran kooperatif sudah terlihat dari tumbuhnya keinginan untuk saling membantu dalam pembelajaran yang rata-rata skor klasikalnya sebesar 82,4 atau dalam kategori tinggi. 


\section{SIMPULAN DAN SARAN}

Adapun kesimpulan dari penerapan model pembelajaran kooperatif tipe TAI selama kegiatan belajar mengajar pada mata pelajaran ekonomi di kelas XII IPS-3 SMA Negeri 1 Percut Sei Tuan sebagai berikut :

a. Hasil belajar siswa dengan menerapkan model pembelajaran kooperatif tipe TAI pada Formatif I menunjukkan rata-rata 72 dengan ketuntasan klasikal $47 \%$ dan Formatif II menunjukkan rata-rata 82 dengan ketuntasan secara klasikal $87 \%$ atau mencapai ketuntasan secara kalsikal dengan peningkatan ketuntasan klasikal $40 \%$.

b. Data aktivitas siswa rata-rata menurut pengamatan pengamat pada Siklus I antara lain menulis/membaca (38\%), mengerjakan LKS (29\%), bertanya sesama teman (8\%), bertanya kepada guru (17\%), dan yang tidak relevan dengan KBM (7\%).

c. Data aktivitas siswa rata-rata menurut pengamatan pada Siklus II antara lain membaca (33\%), mengerjakan LKS (38\%), bertanya sesama teman (20\%), bertanya kepada guru (7\%), dan yang tidak relevan dengan KBM (3\%). Sehingga terjadi perbaikan aktivitas belajar siswa dalam dua siklus.

\section{DAFTAR RUJUKAN}

Dimyati \& Mudjiono. 2006. Belajar dan Pembelajaran. Jakarta : PT Asdi Mahasatya.

Elaine B. Johnson. 2008. Contextual Teaching and Learning (terjemahan Ibnu Setiawan). Bandung : MLC.

Haris Mujiman. 2007. Manajemen Pelatihan Berbasis Belajar Mandiri. Yogyakarta : Pustaka Pelajar.

Jerry dkk. 2007. Accounting Principles. Jakarta: Salemba Empat.

Lie, Anita. 2005. Cooperative Learning Mempraktikkan Cooperative Learning di Ruang-ruang Kelas. Jakarta: Grasindo.

Miles dan Huberman. 1992. Analisis

Data Kualitatif. (diterjemahkan Oleh: Tjetjep Rohedi

Rosidi). Jakarta: Universitas Indonesia.

Napitupula, Tiamsa. 2015. Penerapan Model Pembelajaran Kooperatif Tipe Team Assisted Individualization (TAI) Untuk Meningkatkan Hasil Belajar Siswa Pada Bidang Studi Ekonomi Di Kelas XII IPS-3 Semester II SMA Negeri 1 Percut Sei Tuan T.A.2014/2015. Medan: UD.Toma

Rochiati Wiraartmadja. 2006.

Penelitian Tindakan


Kelas. Bandung: PT

Remaja Rosdakarya.

Suharsimi Arikunto dkk. 2007.

Penelitian Tindakan

Kelas. Jakarta: PT. Bumi

Aksara.

Syaodih Sukmadinata, Nana. 2005.

Metode Penelitian

Pendidikan. Bandung:

Remaja Rosdakarya. 